Jurnal Hukum Mimbar Justitia

Fakultas Hukum Universitas Suryakancana

Vol. 3 No. 2 - Desember 2017 p. 177-203

ISSN: 2477-5681 (Cetak), ISSN: 2580-0906 (Online)

Open Access at: https://jurnal.unsur.ac.id/jmj

\title{
KEBIJAKAN PEMERINTAH MENGENAI PENANGANAN ANAK PELAKU TINDAK PIDANA NARKOBA (STUDI KASUS DI PROVINSI DKI JAKARTA)
}

\author{
Oksimana Darmawan \\ Badan Penelitian dan Pengembangan Hukum dan HAM, \\ Kementerian Hukum dan HAM \\ E-mail: oksimana7@gmail.com
}

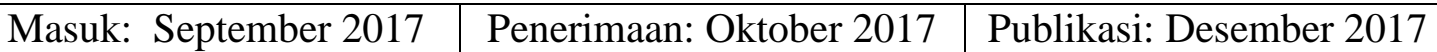

\begin{abstract}
ABSTRAK
Penelitian ini dialatarbelakangi banyaknya kasus anak yang berhadapan dengan hukum terutama terkait penyalahgunaan narkoba. Dalam konsep hak asasi manusia, pemerintah termasuk aparatur penegak hukum dituntut untuk memberikan perlindungan terhadap hak anak menyangkut kepentingan terbaik bagi anak, khususnya terkait rehabilitasi anak, tetapi di sisi lain ada sejumlah regulasi mengatur tentang pidana penyalahgunaan narkoba. Permasalahan penelitian adalah bagaimana penanganaan anak pelaku tindak pidana penyalahgunaan narkoba, dan bagaimana kebijakan rehabilitasi diberikan kepada anak pelaku tindak penyalahgunaan narkoba. Metode penelitian menggunakan pendekatan kualitatif dengan studi kasus. Hasil penelitian menunjukkan UndangUndang Narkotika menyatakan secara tidak langsung anak belum cukup umur diposisikan sebagai korban, karena penyalahgunaan narkoba yang dilakukan anak disebabkan oleh orang yang sudah cukup umur (dewasa), sedangkan pengaturan pidana untuk anak ada dalam Undang-Undang Sistem Peradilan Pidana Anak; belum adanya persamaan persepsi antar para penegak hukum, terkait rehabilitasi medis atau sosial atau pidana penjara bagi anak; rekomendasi tim asesmen terpadu (TAT) sering tidak dimintakan oleh penyidik; balai pemasyarakatan (BAPAS) sering tidak dilibatkan dalam pembuatan TAT. Saran yang diberikan adalah perlu penguatan sinergisitas para aparatur penegak hukum, terutama terkait peran bapas dalam TAT.
\end{abstract}

Kata kunci : Anak, Narkoba, Rehabilitasi, Penegak Hukum, dan Tim Asesmen Terpadu (TAT).

\section{ABSTRACT}

This study is based on the number of cases of children dealing with the law concerning drug abuse. In the concept of human rights, the government including law enforcement officials are required to provide protection concerning the best interests of children, especially child rehabilitation, but on the other hand, there are a number of regulations governing the criminal misuse of narcotics. The research problem is how to arrange children of the perpetrators of criminal acts of drug abuse, and how the rehabilitation policy is given to the child of the perpetrators of the act of drug misuse. The research method used the qualitative approach to a case study. The results of the study show that the Narcotics Act implies that the child is not old enough to be positioned as a victim, since drug abuse is caused by an older person (adult), while the criminal arrangement for children is in the Criminal Justice System Act; the lack of a common perception among law enforcement officials, in relation to medical or social rehabilitation or 
imprisonment for children; the recommendations of an integrated assessment team (IAT) are often excluded from the investigator; corrections bureau is often excluded from making IAT. The advice given is the need to strengthen the synergy of law enforcement officers, especially related to the role of corrections bureau in the IAT.

Keywords: $\quad$ Children, Drugs, Rehab, Law Enforcement, and Integrated Assessment Team (TAT).

\section{PENDAHULUAN}

Saat ini marak terjadi kasus-kasus penyalahgunaan narkoba di berbagai provinsi. Hal ini dapat dilihat dari data Badan Narkotika Nasional Tahun 2014 di seluruh Provinsi Indonesia terkait estimasi jumlah penyalahguna narkoba dan prelevansi populasi penduduk (1059 tahun) dengan total jumlah penyalahguna sebanyak 4.022 .702 orang dan populasi (10-59 tahun) sebanyak 184.175.500 orang. Adapun urutan provinsi dengan jumlah 6 (enam) terbesar Estimasi Jumlah Penyalahguna Narkoba pada Enam Provinsi Tertinggi di Indonesia, disertai Prelevansi dan Populasi Penduduk (10-59 tahun) Tahun 2014 :

1. Jawa Barat dengan jumlah penyalahgunaan 792.206 (tujuh ratus sembilan puluh dua ribu dua rarus enam), prevalensi 2,34\% (dua koma tiga puluh empat persen) pada jumlah polulasi 33.905.400 (tiga puluh tiga juta
Sembilan ratus lima ribu empat ratus) orang;

2. Jawa Timur dengan jumlah penyalahgunaan 568.304 (lima ratus enam puluh delapan ribu tiga ratus empat), prevalensi 2,01 $\%$ (dua koma nol satu persen) pada jumlah polulasi 28.271.400 (dua puluh delapan juta dua ratus tujuh puluh satu empat ratus) orang;

3. Jawa Tengah dengan jumlah penyalahgunaan 452.743 (empat ratus ribu lima puluh dua ribu tujuh ratus empat puluh tiga), prevalensi 1,88 \% (satu koma delapan puluh delapan persen) pada jumlah polulasi 24.131.300 (dua puluh empat juta seratus tigaluph satu tiga ratus) orang;

4. DKI Jakarta dengan jumlah penyalahgunaan 364.174 (tiga ratus enam puluh empat seratus tujuh empat), prevalensi $4,74 \%$ (empat koma tujuh puluh empat) pada jumlah polulasi 7.688 .600 
(tujuh juta enam ratus delapan puluh delapan enam ratus) orang;

5. Sumatera Utara dengan jumlah penyalahgunaan $300.134 \quad$ (tiga ratus ribu seratus tiga puluh empat), prevalensi 3,06\% (tiga koma nol enam) pada jumlah polulasi 9.808.600 (Sembilan juta delapan ratus delapan ribu enam ratus) orang. ${ }^{1}$

6. Banten dengan jumlah penyalahgunaan 177.110 (seratus tujuh puluh tujuh ribu seratus sepuluh), prevalensi $2,02 \%$ (dua koma nol dua) pada jumlah polulasi 8.770.800 (delapan juta tujuh ratus tujuh puluh delapan ratus) orang.

Banyaknya jumlah penyalahguna narkoba perlu menjadi perhatian banyak pihak mengingat penyalahgunaan narkoba dapat mengalami peningkatan tiap tahunnya bahkan telah menyentuh pada anak-anak usia sekolah yang seharusnya menimba ilmu untuk masa depan. Hal ini dapat dilihat terdapat anak usia sekolah yang mengkonsumsi ataupun menjadi pengedar narkoba. Bila

1 Badan Narkotika Nasional, Laporan Akhir Survey Nasional Perkembangan Penyalahguna Narkoba Tahun Anggaran 2014, tanpa penerbit, Jakarta, 2014, hlm. 53. dilihat dari jumlah penyalahguna narkoba dalam kelompok pelajar berdasarkan jenis narkoba yang paling dominan digunakan, adalah shabu. ${ }^{2}$

Seseorang yang melakukan pidana terkait dengan narkoba akan berhadapan dengan negara melalui aparatur penegak hukumnya berdasarkan Undang-Undang Nomor 35 Tahun 2009 tentang Narkotika dan Undang-Undang Nomor 5 Tahun 1997 tentang Psikotropika, termasuk anak. Anak yang terkena tindakan pidana karena menjadi pelaku penyalahguna narkoba juga akan diproses melalui peraturan perundang-undangan yang sama walaupun pada proses peradilannya berbeda dengan orang dewasa. Hal ini berkaitan perlindungan khusus yang diberikan kepada anak oleh negara sebagaimana yang diamanatkan dalam Pasal 59 ayat (1) dan ayat (2) Undang-Undang Nomor 35 Tahun 2014 tentang Perubahan Atas UndangUndang Nomor 23 Tahun 2002 tentang Perlindungan Anak, yaitu pemerintah, pemerintah daerah, dan lembaga negara lainnya berkewajiban dan bertanggung jawab untuk memberikan perlindungan khusus kepada Anak, antara lain anak

2 Badan Narkotika Nasional, Ibid, hlm. 20. 
yang berhadapan dengan hukum; dan korban penyalahgunaan narkotika, alkohol, psikotropika, dan zat adiktif lainnya.

Berkenaan dengan hal tersebut, Bagir Manan mengemukakan bahwa anak-anak di lapangan hukum pidana diperlakukan sebagai "orang dewasa kecil”, sehingga seluruh proses perkaranya kecuali di Lembaga Pemasyarakatan dilakukan sama dengan perkara orang dewasa. Perlakuan yang berbeda hanya pada waktu pemeriksaan di sidang pengadilan, sidang untuk perkara anak dilakukan secara tertutup (Pasal 153 ayat (3) KUHAP) dan petugasnya (hakim dan jaksa) tidak memakai toga. Semua itu terkait dengan kepentingan fisik, mental dan sosial anak yang bersangkutan. ${ }^{3}$

Perlakuan berbeda yang diberikan oleh anak, juga terkait usaha diversi. Dalam Undang-Undang No. 11 Tahun 2012 tentang Sistem Peradilan Pidana Anak (UU SPPA), pada Pasal 7 secara garis besar dinyatakan pada tingkat penyidikan, penuntutan, dan pemeriksaan perkara Anak di pengadilan negeri wajib diupayakan Diversi; dan diversi diberikan pada ancaman pidana penjara di bawah

3 Bagir Manan di dalam buku Gatot Supramono, Hukum Acara Pengadilan Anak, Djambatan, Jakarta, 2000, hlm. 9. tujuh tahun serta bukan pengulangan tindak pidana.

Oleh karena itu tidak semua anak dapat diberikan diversi pada kasus narkoba yang dihadapinya. Menurut Asrorun selaku Ketua Komisi Perlindungan Anak Indonesia (KPAI) berpendapat bahwa seharusnya anakanak yang terlibat tersebut dimasukkan ke dalam panti rehabilitasi, bukannya ke dalam penjara untuk direhabilitasi, karena diposisikan sebagai korban. Namun kenyataannya, ada sekian banyak anak yang seharusnya mendapatkan rehabilitasi, tetapi justru malah di penjara. ${ }^{4}$

Hal tersebut sangat 180 memprihatinkan mengingat anak pelaku penyalahgunaan narkoba juga memiliki hak untuk mendapatkan perlindungan sesuai yang tercantum dalam peraturan perundang-undangan. Oleh karena itu, dipandang perlu dilakukannya Penelitian tentang Penanganan Anak Pelaku Tindak Pidana Narkoba dengan mengambil lokasi di DKI Jakarta sebagai studi kasus.

4 Risman, Jumlah Anak di Bawah Umur yang Jadi Pengedar Narkoba Meningkat, http://nasional.harianterbit.com/nasional/2 015/04/27/26608/25/25/Jumlah-Anak-diBawah-Umur-yang-Jadi-Pengedar-NarkobaMeningkat, diunduh pada Selasa, 7 Februari 2016, Pukul 10.39 WIB. 
Berdasarkan latar belakang di atas yang telah diuraikan, maka permasalahan dalam penelitian ini adalah Bagaimana gambaran secara umum penanganan anak pelaku tindak pidana penyalahgunaan narkoba? dan Bagaimana kebijakan rehabilitasi, baik medis maupun sosial diberikan kepada anak pelaku tindak pidana penyalahgunaan narkoba?

\section{METODE PENELITIAN}

\section{Metode Pendekatan}

Metode penelitian menggunakan pendekatan kualitatif melalui studi literatur dan studi lapangan dengan teknik wawancara. Salah satu pendekatan kualitatif adalah studi kasus.

Menurut Creswell, apabila kita akan memilih studi untuk suatu kasus, dapat dipilih dari beberapa program studi atau sebuah program studi dengan menggunakan berbagai sumber informasi yang meliputi: observasi, wawancara, materi audio-visual, dokumentasi dan laporan. Konteks kasus dapat "mensituasikan" kasus di dalam settingnya yang terdiri dari setting fisik maupun setting sosial, sejarah atau setting ekonomi. Sedangkan fokus di dalam suatu kasus dapat dilihat dari keunikannya, memerlukan suatu studi (studi kasus intrinsik) atau dapat pula menjadi suatu isu (isu-isu) dengan menggunakan kasus sebagai instrumen untuk menggambarkan isu tersebut (studi kasus instrumental). Ketika suatu kasus diteliti lebih dari satu kasus hendaknya mengacu pada studi kasus kolektif. ${ }^{5}$ Untuk itu Lincoln Guba mengungkapkan bahwa struktur studi kasus terdiri dari masalah, konsteks, isu dan pelajaran yang dipelajari. ${ }^{6}$

\section{Spesifikasi Penelitian}

Penelitian hukum ini adalah deskriptif kualitatif yang sebenarnya merupakan tata cara penelitian yang menghasilkan data deskriptif, yaitu apa yang dinyatakan oleh responden (informan) secara tertulis atau lisan, dan perilaku nyata. $^{7}$

Terkait sumber data berasal dari data primer dan sekunder. Data primer dikumpulkan berdasarkan hasil wawancara terhadap para narasumber. Data sekunder berupa peraturan

\footnotetext{
5 John W. Creswell, Qualitative Inquiry and Research Design: Choosing Among Five Tradition, SAGE Publications, London, 1998, hlm. 61.

${ }^{6} \mathrm{Ibid}, \mathrm{hlm} .61-62$.

7 Soerjono Sukanto, Pengantar Penelitian Hukum, Universitas Indonesia Press, Cetakan 3, Jakarta, 1986, hlm. 32.
} 
perundangan yang terkait dengan permasalahan yang dibahas, studi dokumen berbasis dokumen kebijakan lokal, data statistik, laporan penelitian terdahulu, dan beberapa dokumen yang terkait.

\section{Tahap Penelitian}

Studi Literatur merupakan teknik pengumpulan bahan berbasis kajian dokumen. Informasi yang ingin diketahui adalah mengenai pemikiran yang mendasari perencanaan, programprogram, maupun laporan kegiatan baik yang tertulis maupun yang tidak tertulis terkait seluruh proses perencanaan tersebut.

Penelitian Lapangan (field works) merupakan teknik pengumpulan data yang dilakukan secara langsung untuk membantu kerja-kerja penganalisaan bahan. Diantaranya terkait dengan pencarian data lapangan terhadap pemenuhan target yang telah direncanakan terwujud dalam kenyataan.

$$
\text { Studi bermaksud mengurai }
$$
mengenai kesesuaian perlindungan hak anak pelaku tindak pidana penyalahgunaan narkoba serta kendala yang dihadapi.
Wawancara dalam kegiatan penelitian ini menggunakan teknik wawancara berstruktur dan tidak berstruktur. Wawancara berstruktur dilakukan berdasarkan penggunaan daftar pertanyaan kombinasi terbuka maupun tertutup; sedangkan teknik wawancara tidak berstruktur, yaitu mempergunakan teknik yang diyakini peneliti untuk mendapatkan informasi maupun pendapat informan secara lisan berdasarkan suatu pedoman atau catatan pokok-pokok yang tertera dalam pedoman wawancara.

\section{Pengolahan Data}

Penelitian mempergunakan metode analisa kualitatif dengan mengolah hasil pengumpulan data primer berdasarkan hasil studi lapangan serta pengumpulan data sekunder untuk dilanjutkan dengan analisa berbasis critical review terhadap peraturan perundangan, studi literatur, data statistik, laporan penelitian terdahulu, dan beberapa dokumen yang terkait.

\section{PEMBAHASAN}

Hukum merupakan sarana kontrol sosial diwujudkan dalam sanksi sanksinya, yang berkolerasi antara penerapan hukum sebagai kebijakan 
hukum, dimana kebijakan menurut Aristoteles adalah keadilan, yaitu suatu kebijakan politik yang aturan-aturannya menjadi dasar dari peraturan negara. ${ }^{8}$

Khususnya hukum pidana yang dilakukan melalui kebijakan kriminal (criminal policy) dan kebijakan sosial (social policy). ${ }^{9}$ Seperti halnya kebijakan pemerintah mengenai penanganan anak pelaku tindak pidana narkoba.

\section{Penanganan anak pelaku tindak pidana penyalahgunaan narkoba}

Kasus anak pelaku tindak pidana penyalahgunaan narkoba dalam proses penanganannya selalu akan melibatkan pihak-pihak terkait yaitu pihak Kepolisian, Balai Pemasyarakatan, Kejaksaan dan Pengadilan seperti pada kasus pidana lainnya. Akan tetapi kasus

8 M. Rendi Aridhayandi, Focus Group Discution Mengenai Pemahaman Perubahan Aturan Hukum Indikasi Geografis Bagi Masyarakat Pelestari Padi Pandanwangi Cianjur (MP3C) Sebagai Pemegang Hak Indikasi Geografis Terdaftar, Journal of Empowerment, Volume. 1, Nomor. 2, Desember 2017, hlm. 90.

9 Aji Mulyana, Perlindungan Hukum Terhadap Perempuan dan Anak Akibat Tindak Pidana Abortus Provokatus Criminalis, Jurnal Wawasan Yuridika, Volume. 1, Nomor. 2, Sepetmber 2017, hlm. 139-154. narkoba menjadi salah satu kasus yang memerlukan perhatian khusus dalam penanganannya.

Terkait kategori anak tindak pidana narkoba yang ditangkap kepolisian, menurut Kanit Narkoba Polda Metro Jaya ${ }^{10}$, ada dua kategori anak yang berhadapan dengan hukum khusus untuk narkoba, yaitu anak sebagai pengguna yang sifatnya adalah pemakai dan bisa kecanduan, dan anak sebagai penyalahguna kegiatannya mencakup menyuruh untuk melakukan dan masuk dalam kategori bandar (pengedar). Dalam menangani perkara anak tersebut, kepolisian berpegang pada hukum, artinya jika hukum mengatur, maka anak tidak diperbolehkan dikenakan pidana, sehingga polisi tidak akan melakukan penyidikan lebih lanjut terhadap anak yang tidak melakukan suatu perbuatan yang dilanggar (pidana). Dalam hal ini, jika hasil penyidikan diperoleh anak sebagai pengguna, maka anak tidak dikenakan pemidanaan, tetapi dilakukan rehabilitasi.

Secara umum, penyidikan kasus anak yang berhadapan dengan hukum, diatur dalam undang-undang

\footnotetext{
10 Wawancara dengan Kanit Polda Metrojaya
} pada tanggal 28 Maret 2016 
perlindungan anak, sehingga polisi juga melihat kepentingan terbaik untuk anak. Namun, untuk kasus anak yang tersangkut peredaran narkoba, harus dilakukan penyidikan rangkaian jaringan narkoba sampai pada jaringan tingkat atas. Hal ini berarti bahwa rangkaian jaringan narkoba merupakan jaringan khusus, jika penyelidikan dihentikan maka akan membahayakan orang lain karena peredaran narkoba masih ada.

Oleh karena itu dalam penyidikan, polisi berharap agar anak tidak termasuk dalam golongan penyalahguna, karena berbeda proses hukum yang akan dijalani oleh anak. Anak sebagai pengguna proses yang dijalani adalah dilakukan rehabilitasi, sedangkan anak sebagai penyalahguna menjalani proses hukum di pengadilan.

Menurut Kanit Narkoba Polda Metro Jaya, kewenangan polisi ada pada tahap penyidikan, sehingga tidak masuk di Kejaksaan dan lebih diarahkan pada diversi. Pada tahap penyidikan, khususnya untuk narkoba dibutuhkan waktu untuk melakukan penelitian selama tiga kali 24 jam dan dikali 2 . Waktu penyidikan tersebut digunakan polisi untuk memahami dari seluruh proses pengungkapan narkoba dan tidak bisa selesai dalam waktu singkat, sehingga membutuhkan waktu untuk menentukan barang bukti tersebut positif atau tidak, proses hukum mengerti atau tidak, bahkan kalau memungkinkan dipanggil orang tua/wali anak.

Penyidikan bisa membutuhkan waktu lama, hal ini antara lain, disebabkan kasus nakoba bersentuhan dengan oknum aparatur penegak hukum lainnya. Salah satu contoh kasus adalah adanya keterlibatan oknum penegak hukum yang sudah diserahkan ke instansinya, sedangkan anak sudah pernah menjalani masa hukuman delapan bulan dan bebas pada bulan Januari 2015, ternyata tertangkap lagi tahun 2016 dengan usia 15 tahunan. Pada waktu tertangkap tahun 2015, si anak menyatakan bahwa ia dijebak. Pada tahun 2016, si anak menyatakan bahwa ia mempunyai atasan yang sering memberikan uang, sedangkan oknum TNI membeli narkoba dari anak tersebut. Hal ini membuat lamanya waktu penyidikan, sedangkan uji laboratorium terhadap urin juga membutuhkan waktu lama, karena alat uji laboratorium terpisah dan bisa diketahui jenis narkoba yang dipakai. Hasil uji laboratorium menyatakan 
untuk anak, hasilnya adalah negatif; sedangkan oknum TNI hasilnya positif.

Berbeda dengan kasus yang lain, seperti razia di diskotik dan dilanjutkan dengan tes urin, namun apabila hasil tes urin banyak yang positif, dan semua orang yang positif narkoba diajukan ke pengadilan, maka lembaga pemasyarakatan akan penuh. Oleh sebab itu, pihak kepolisian menyerahkan ke BNN untuk dilakukan rawat jalan (konseling) atau ditempatkan di tempat rehabilitasi.

Mengenai pembuatan berita acara pemeriksaan (BAP), anak harus didampingi oleh pengacara, Bapas, dan orang tua/wali anak. Kepolisian akan memanggil orang tua/wali anak, Bapas untuk mendampingi anak, dan pengacara. Sedangkan bila tidak ada pengacara, maka polisi akan menyewakan pengacara. Proses ini paling lama tiga jam kalau siang hari, sedangkan untuk Bapas kalau malam tidak ada, seharusnya Bapas 24 jam, tetapi Bapas memberikan kelonggaran untuk dilanjutkan pemeriksaan, dan besoknya pihak Bapas datang ke kepolisian. $^{11}$

${ }^{11}$ Wawancara dengan Kanit Narkoba Polda Metro Jaya pada 28 Maret 2016
Dalam hal anak yang masuk dalam persidangan, menurut Hakim Gultom, berkas yang masuk pengadilan merupakan berkas yang telah sampai pada proses penyidikan, apabila kepolisian menyatakan tidak dilakukan penyidikan, maka tidak masuk ke pengadilan, sehingga tidak mungkin P21 (istilah berkas perkara sudah lengkap atau sudah siap disidangkan). ${ }^{12}$

Mengenai pandangan hakim terkait penyalahgunaan narkoba oleh anak, pada hakekatnya, hakim tidak menginginkan untuk mempidana anak, tetapi hakim akan melihat kasus perkasus (chase by chase). Intinya hakim tidak ingin menghilangkan masa depan anak, tetapi dalam perspektif jaksa tidak terlepas dari penuntutan dan menghukum, karena pihak penuntut umum (bisa dikatakan) tidak pernah sependapat dengan hakim. Oleh sebab itu, apabila jaksa tidak sepaham dengan hakim, maka secara otomatis jaksa mengajukan banding. Sepengetahuan Hakim Gultom belum pernah ada tuntutan jaksa selain tuntutan pemidanaan, walaupun anak tersebut melakukan pertama kali, sehingga jaksa tidak pernah menuntut, seperti anak

12 Wawancara dengan hakim di Pengadilan Negeri pada tanggal 29 Maret 2016 
dipekerjakan sosial atau hukuman dalam rangka untuk pengawasan.

Dalam persidangan, hakim sudah melaksanakan amanat dalam UndangUndang Sistem Peradilan Pidana Anak, bahwa diversi dapat dilakukan, sepanjang dakwaan memenuhi unsur Pasal 127, yaitu penggunaan narkoba untuk diri sendiri, tetapi juga dilihat/dinilai kasus per-kasus. Penilaian kasus per-kasus ini, dikarenakan ditemukan beberapa kasus pelibatan anak dalam peredaran narkoba, pada awalnya anak hanya ikut-ikutan sebagai perantara, seiring berjalannya waktu anak menjadi terbiasa, dan akhirnya dimanfaatkan oleh pihak jejaring narkoba ini. Selain itu dari penglihatan hakim, jika usia anak antara 17 sampai 18 tahun dibandingkan dengan postur tubuh anak, maka sulit untuk dibedakan antara anak dengan orang dewasa, karena postur tubuh anak terlihat seperti orang dewasa yang didukung dengan pengetahuannya yang sangat paham mengenai narkoba.

Dalam upaya diversi untuk anak penyalahgunaan narkoba, pertimbangan hakim didasarkan, antara lain, dari temuan penyidik, dan rekomendasi Balai Pemasyarakatan (Bapas), tetapi selama menjadi hakim belum pernah menerima hasil rekomendasi dari TAT.

Dari pihak jaksa, menurut hakim temuan penyidik juga ikut berpengaruh pengajuan banding oleh Jaksa, karena Jaksa dalam tuntutannya juga mempertimbangkan temuan penyidik. Hal ini berarti Jaksa tidak mengajukan banding, karena mempertimbangkan dari temuan penyidik bahwa anak layak untuk di diversi, tetapi jaksa juga melihat kasus per-kasus.

Selanjutnya, untuk penangangan pelaku tindak pidana penyalahgunaan narkoba di Badan Narkotika Nasional Provinsi DKI Jakarta (BNNP Jakarta), pada bidang rehabilitasi mempunyai program wajib lapor. Menurut Wahyu Wulandari, pihak BNNP DKI Jakarta "jemput bola" mendatangi sekolahsekolah, karena pengguna usia remaja sifatnya masih banyak yang mencoba narkoba. Program ini juga didukung pihak sekolah yang memberikan waktu khusus bagi BNNP DKI Jakarta untuk melakukan konseling, sehingga rehabilitasinya bersifat rawat jalan. ${ }^{13}$

Menurut informan mengenai upaya rehabilitasi anak di tahap ajudikasi, anak dengan barang bukti

13 Wawancara dengan Kepala Bidang Rehabilitasi BNNP DKI Jakarta pada tanggal 30 Maret 2016 
tetap diproses hukum, walaupun segelintir ganja, jika dinyatakan berkas sudah lengkap oleh kejaksaan, maka dilimpahkan ke pengadilan. Namun, perlakuan terhadap anak dalam proses ajudikasi dibedakan dengan orang dewasa, seperti di pengadilan dilakukan sidang tertutup (tidak diperbolehkan ditonton umum) dan prosesnya harus selesai selama 15 hari, sedangkan untuk vonis ditentukan oleh hakim, apakah ditempatkan di lembaga pemasyarakatan atau masuk dalam rehabilitasi. Di BNNP DKI Jakarta ratarata menerima setelah vonis hakim untuk direhabilitasi, sebagian hasil tangkapan dari tim asesmen terpadu (TAT),

Tim asesmen terpadu merupakan tim yang memberikan rekomendasi sebelum masuk dalam pengadilan (praajudikasi). TAT adalah tim gabungan yang terdiri dari unsur kepolisian, kejaksaan, BNN, dan Kanwil Kementerian Hukum dan HAM tetapi tidak sebagai penyidik utama. Adapun penyidik utama merupakan instansi penangkap anak penyalahgunaan narkoba, bisa dari unsur kepolisian, kejaksaan atau BNN, sehingga penyidik utama tidak termasuk dalam tim asesmen terpadu (TAT).
Dalam hal legitimasi berupa Surat Keputusan TAT kasus penyalahgunaan narkoba, biasanya dibuat oleh BNNP Jakarta (untuk tingkat provinsi). Dalam Surat Keputusan tersebut disebutkan anggota TAT. Dalam hal ini BNNP DKI Jakarta belum pernah menjadi penyidik, karena tidak menangkap anak dengan barang bukti. Menurut Informan saat bertugas pihak BNNP DKI Jakarta, belum pernah diminta oleh penyidik untuk melakukan asesmen dalam TAT, padahal di dalam TAT ada rekomendasi yang merupakan hasil rapat seluruh anggota tim dan ditandatangani sebagai bentuk persetujuan rekomendasi tersebut. ${ }^{14}$

Selanjutnya, dalam standar operasional prosedur (SOP), anggota TAT melakukan rapat TAT adalah sejak anak tertangkap enam kali 24 jam (6 x 24 jam atau enam hari). Hasil rapat TAT berupa rekomendasi yang diajukan ke pengadilan. Di pengadilan, peran yang lebih besar ada pada penyidik utama untuk mengikuti kasus anak selama proses pengadilan sampai selesai, sedangkan peran TAT bersifat

\footnotetext{
14 Tanggapan Wahyu Wulandari Pegawai BNNP DKI Jakarta, saat presentasi akhir pada Bulan Agustus 2016 di Balitbang Hukum dan HAM.
} 
pemantauan menyangkut rekomendasi yang diajukan ke hakim.

Lain hal pada anak penyalahgunaan narkoba yang melaporkan diri. Menurut Kepala Bidang Rehabilitasi BNNP Jakarta, anak akan menjalani tes urin dan dilakukan asesmen. Dari hasil asesmen ditentukan apakah anak diberikan tindakan rawat jalan atau rawat inap yang didasarkan pada tingkat kecanduan anak, seperti pada kasus anak yang masih coba-coba memakai narkoba, maka diberikan rawat jalan dengan konseling. Sedangkan untuk tingkat ketergantungan/kecanduan narkoba berat akan diberikan rawat inap. Untuk rawat inap dirujuk pada Balai Besar Rehabilitasi BNN di Lido-Bogor atau rumah sakit ketergantungan obat (RSKO) di Cibubur. Di Lido-Bogor sekarang sudah tersedia untuk anak, tetapi di RSKO-Cibubur menurut informasi pegawai RSKO belum ada anak yang menjalani rawat inap.

Meskipun faktor penyembuhan utama ditentukan oleh anak itu sendiri, tetapi peranan konselor sebagai pihak yang melakukan konseling juga berpengaruh, seperti konselor akan menggali sejauhmana motivasi anak untuk berhenti mengkonsumsi narkoba

$$
\begin{aligned}
& \text { dan memberikan pencerahan, } \\
& \text { selanjutnya anak yang akan }
\end{aligned}
$$
memutuskan sendiri, sehingga konselor sebagai pihak yang memberikan penilaian dari hasil konseling.

\section{Kebijakan rehabilitasi yang diberikan kepada Anak Pelaku} Tindak Pidana Penyalahgunaan Narkoba

Menurut Hakim Gultom, pengalaman hakim rata-rata menunjukkan bahwa Jaksa Penuntut Umum tidak pernah menuntut supaya anak direhabilitasi, baik medis maupun sosial, atau di bawah pengawasan. ${ }^{15}$ Akan tetapi tuntutan Jaksa Penuntut Umum berupa pemidanaan badan, sehingga terdapat perbedaaan antara penilaian hakim dengan jaksa. Penilaian hakim menyangkut rehabilitasi ini, tidak saja menyangkut anak, tetapi juga orang dewasa. Jika menurut penilaian hakim orang dewasa sebagai pengguna, maka ditempatkan di rehabilitasi, seperti Panti Rehabilitasi BNN di Lido, Bogor.

Oleh karena itu, putusan yang diberikan hakim adalah putusan terbaik bagi anak. Hal ini dikarenakan hakim berpandangan bahwa demi kepentingan

\footnotetext{
15 Wawancara dengan hakim di Pengadilan
} Negeri pada tanggal 29 Maret 2016. 
masa depan anak, maka anak yang membutuhkan rehabilitasi seharusnya dilakukan rehabilitasi sosial dan medis, sehingga harus ditempatkan di tempat rehabilitasi, kecuali bila menurut penilaian hakim, si anak tidak bisa dibina atau pernah dihukum dan tidak ada keinsafan, maka pemidanaan yang menjadi jalan terakhir.

Berkenaan hasil penelitian kemasyarakatan (PK) dari Bapas, menurut Hakim hasil litmas sudah cukup baik sesuai standar, sehingga dapat dijadikan pertimbangan hakim. Dalam pandangan hakim, anak yang berhadapan dengan hukum $(\mathrm{ABH})$ berhak memperoleh bimbingan pendampingan dan juga mendapatkan hasil penelitian yang dilakukan oleh Bapas berupa Litmas. Semua $\mathrm{ABH}$ harus didampingi, dan juga hasil Litmas tersebut dilampirkan dalam berkas lengkap sebelum persidangan. Selanjutnya hakim meminta pendapat dan tanggapan kepada petugas Pembimbing Kemasyarakatan terhadap hasil litmas yang dilakukannya. Namun, dalam putusan hakim didasarkan atas data dan fakta di persidangan, sedangkan hasil litmas dipakai sebagai pertimbangan, sehingga hasil litmas tersebut harus sesuai dengan fakta yang ada. Walaupun demikian, hakim juga membutuhkan hasil litmas antara lain mengenai pendidikan anak, hubungan orang tua dengan anak, latar belakang anak menyalahgunakan narkoba, sehingga bisa diketahui apakah ada penelantaran orang tua terhadap anak, dan kurangnya pengasuhan yang baik dari orang tua.

Mengenai hambatan yang dihadapi di Pengadilan, Hakim Gultom berpendapat, bahwa pertama, sebetulnya pemerintah belum siap untuk menempatkan anak yang bermasalah dengan hukum di luar pemidanaan, sehingga pemerintah bisa melakukan penempatan anak di luar lapas. Hal ini bisa dilakukan oleh Kementerian Sosial untuk bisa menampung anak penyalahgunaan narkoba. Selain itu juga tempat rehabilitasi ini perlu diperbanyak, karena bisa over capacity. Kedua, para petugas yang menangani $\mathrm{ABH}$ penyalahgunaan narkoba belum sama persepsinya mengenai anak yang bermasalah dengan hukum, sehingga perlu disepahamkan.

Menurut pengalaman Hakim Gultom $^{16}$, penampungan anak di luar lapas ini penting, karena selama

\footnotetext{
${ }^{16}$ Wawancara dengan Hakim Pengadilan Negeri tanggal 29 Maret 2016.
} 
menjadi hakim yang menangani anak yang berhadapan dengan hukum khususnya narkoba, apabila memutuskan anak di pekerja sosial bagi anak yang di luar kasus narkoba, kenyataannya tidak bisa dilaksanakan. Hal ini dikarenakan antar instansi tidak memiliki jejaring, termasuk juga Jaksa tidak tahu tempat untuk anak dipekerjakan sosial. Hal ini tidak menutup kemungkinan kasus penyalahgunaan narkoba oleh anak, dimana pada prinsipnya kalau anak tersebut sebagai pecandu, hukumnya harus direhabilitasi, baik medis atau sosial, sehingga dibutuhkan banyak tempat penampungan rehabilitasi agar tidak melebihi kapasitas.

Hal yang berbeda diungkapkan oleh pihak Bapas Kelas I Jakarta Selatan ${ }^{17}$. menurut Informan selama ditugaskan di Bapas Kelas 1 Jakarta Selatan belum pernah diminta untuk menjadi anggota TAT. Hal ini terkait putusan rehabilitasi oleh Hakim biasanya harus terdapat rekomendasi dari TAT, sehingga Hakim jarang sekali menyarankan untuk melakukan

17 Wawancara dengan Kepala Bimbingan Klien Anak, Bapas Kelas I Jakarta Selatan, pada tanggal 17 Maret 2016. rehabilitasi, karena tidak adanya rekomnedasi rehabilitasi dari TAT.

Jarangnya mengambil putusan rehabilitasi, terlebih pada anak yang kurang mampu yang biasanya untuk membeli narkoba secara patungan. Dalam kasus tersebut, pihak Bapas melihat faktanya bahwa mereka sebagai pengguna, tetapi hakim menanyakan apa latar belakang mereka sebagai pengguna padahal bila dilihat dari barang buktinya saja bisa disebut hanya pengguna. Hal tersebut dapat terlihat pada hasil putusan hakim tahun 2015 dan 2016 sebagai berikut :

Tabel 2

Data Putusan Hakim

\begin{tabular}{|c|c|c|c|}
\hline No & Tahun & $\begin{array}{l}\text { Jumlah } \\
\text { Klien }\end{array}$ & Keterangan \\
\hline 1 & 2015 & 13 orang & $\begin{array}{ll}- & \text { Saran } \\
\text { Rehabilitasi } 3 \\
\text { - } & \text { Putusan } \\
\text { Pengadilan } \\
\text { Pidana Penjara } \\
\text { 13 Orang }\end{array}$ \\
\hline 2 & 2016 & $\begin{array}{l}3 \text { orang } \\
\text { (sampai } \\
\text { Maret } \\
2016 \text { ) }\end{array}$ & $\begin{array}{ll}\text { - } & \text { Saran } \\
\text { Rehabilitasi } 3 \\
\text { - } & \text { Putusan } \\
\text { Pengadilan } \\
\text { Pidana Penjara 1 } \\
\text { Orang, 2 orang } \\
\text { dalam proses } \\
\text { persidangan }\end{array}$ \\
\hline
\end{tabular}

Sumber: Bapas Kelas I Jakarta Selatan

Pada kasus anak yang terlibat narkoba, pihak Bapas Kelas I Jakarta Selatan selalu menyarankan untuk dilakukan rehabilitasi di tempat milik Kemensos daerah Ciputat dan 
Cipayung. Akan tetapi Bapas juga harus melihat dari situasi yang ada. Hal ini dikarenakan terdapat tren bahwa anak selalu dimanfaatkan bukan sebagai pelaku utama. Bandar narkoba melihat bahwa hukuman anak adalah setengah dari masa pidana dan banyak kemudahan dari sistem yang ada. Bapas kuatir bahwa bandar narkoba menggunakan anak sebagai jaringan atau kaki tangannya. Bapas menyadari ketika anak kedapatan membawa banyak narkoba, maka pihak Bapas tidak mungkin menyarankan untuk melakukan rehabilitasi dan secara otomatis harus melewati suatu lembaga yang dapat memiliki kegiatan positif bagi si anak.

Selanjutnya di pihak kejaksaan, walaupun jaksa berkeinginan untuk tetap melanjutkan proses hukum bagi anak pelaku penyalahgunaan narkoba, namun jaksa tidak akan melakukan penuntutan pada anak yang mendaftarkan diri untuk rehabilitasi secara sukarela. Dalam hal ini terdapat institusi penerima wajib lapor (IPWL), sehingga anak yang mendaftarkan diri, seperti ke Puskesmas atau rumah sakit yang ditunjuk melalui proses kesukarelaan. Berbeda dengan anak yang sudah ditangkap dengan BNN atau kepolisian, si anak tetap diproses secara hukum. ${ }^{18}$

Salah satu IPWL yang dirujuk berdasarkan Surat Keputusan Kementerian Kesehatan adalah Rumah Sakit Fatmawati, yang memiliki Program Terapan Rumatan Metadon. Dalam pandangan medis untuk memulihkan pecandu narkoba, menurut Dokter Rumah Sakit Fatmawati ${ }^{19}$, untuk pengguna jarum suntik narkoba berupa heroin atau putau, diberikan subtitusi atau obat pengganti yang namanya metadon. Program pemulihan dengan memakai metadon ini mulai berjalan sejak tahun 2003, rata-rata pengguna aktif memakai pada usia 15 sampai 29 tahun dan sudah lama mengkonsumsi narkoba tersebut, sehingga mereka sering masuk ke rumah sakit ketergantungan obat (RSKO), karena pengguna narkoba jenis ini sudah sulit disembuhkan, selalu rileks, dan sering kambuh. Karena sulit disembuhkan ini, mereka mengikuti program rawat jalan, tetapi pengguna datang setiap hari untuk meminum metadon di loket sebagai substitusi atau pengganti dari heroin yang mereka gunakan atau suntikkan.

\footnotetext{
18 Pernyataan staf/pejabat Kejaksaan Negeri pada Presentasi Awal Penelitian ini tanggal 1 maret 2016

19 Wawancara dengan dokter RS Fatmawati
} 
Namun, program ini sifatnya jangka panjang, pengguna tidak bisa langsung berhenti cepat dari program ini, karena masih ada kekambuhannya, angka kekambuhan bisa sekitar 60\% kambuh, artinya pengguna bisa menggunakan narkoba lagi, sehingga digantikan oleh obat ini yang diminum setiap hari dalam jangka panjang.

Terkait masalah anak yang berhadapan dengan hukum di persidangan dalam upaya diversi, sering dokter dari pihak rumah sakit menjadi saksi ahli di pengadilan, terutama di Pengadilan Negeri Jakarta Barat. Selama menjadi saksi ahli, dijelaskan bahwa penggunaan narkoba juga merupakan penyakit kejiwaan dan juga penyakit otak, sehingga pengguna perlu untuk direhabilitasi. Oleh karena itu di tempat rehabilitasi, mereka dilatih coping mekanisme, yaitu apa yang mereka ingin lakukan atau coping skil, yaitu latihan untuk mengendalikan keinginan atau sugesti dalam istilah pengguna. Namun, permintaan menjadi saksi ahli adalah dari orang tua dan dari pihak pengadilan, belum pernah dihubungi oleh pihak kepolisian atau kejaksaan.

Dalam hal perannya di lembaga pemasyarakatan, selama ini pihak rumah sakit melakukan supervisi untuk menjadi pembimbing di klinik Lapas Pemuda Tangerang, yang juga merupakan salah satu satelit RS Fatmawati. Adapun pihak RS Fatmawati mempunyai 11 satelit, antara lain, Cikopasari, Cipondo, Keramat Jati, Petamburan, Senin-Johar Baru; sedangkan RSKO juga mempunyai satelit, sehingga Indonesia memiliki sekitar 60 satelit Program Terapi Rumatan Metadon (PTRM). Pendampingan di satelit tersebut, merupakan instruksi dari Kementerian Kesehatan.

Mengenai hambatan yang dialami selama rehabilitasi rawat jalan, menurut Dokter Rumah Sakit Fatmawati, pengguna narkoba, khususnya heroin dan putau merupakan penyakit otak, terkadang mereka ada gejala sisa penurunan daya pikir dan malas, sehingga diperlukan menciptakan lapangan pekerjaan bagi mereka, seperti kerjasama dengan Kementerian Sosial. Lapangan kerja sangat diperlukan untuk pemulihan pengguna narkoba, baik fisik maupun psikis tidak sempurna, seperti berkurangnya kecerdasan kognisi.

Dalam hal pengobatan, mereka membayar sendiri biaya untuk pengobatannya. Obat yang digunakan 
saat ini berbentuk sirup karena obat yang basa terasa pahit. Untuk pengobatan, dapat menggunakan kartu BPJS dan jumlah pasien yang menggunakan BPJS saat ini sekitar 20 orang dengan memenuhi beberapa persyaratan, yang salah satunya ada rujukan puskesmas ke Rumah Sakit Umum Daerah (RSUD). Harga obatobatan yang disediakan sangat terjangkau dibanding saat mereka masih membeli putau dengan harga beberapa ratus ribu perhari. Untuk harga metadon yaitu Rp. 15.000,/perhari /sekali minum sudah termasuk konsultasi dokter jika anaknya sakit minta berbagai saran. ${ }^{20}$

Anak pelaku tindak pidana penyalahgunaan narkoba menjadi salah satu permasalahan yang penanganannya belum maksimal. Hal ini dikarenakan penanganan anak yang biasanya mengacu pada Undang-Undang Sistem Peradilan Pidana Anak, namun seringkali berbenturan dengan UndangUndang nomor 35 tahun 2009 tentang Narkotika.

Permasalahan yang muncul adalah dari perbedaan persepsi antar para aparat penegak hukum yang

20 Wawancara dengan pejabat dari RS Fatmawati kemudian menimbulkan penanganan penyalahguna narkotika yang berbedabeda pula. Sangat sering terjadi penyidik menggunakan pasal yang tidak seharusnya diberikan kepada pecandu dan korban penyalahgunaan narkotika, terlebih lagi bagi pelaku yang belum dewasa (anak). Jaksa Penuntut Umum pun hanya bisa melanjutkan tuntutan yang sebelumnya sudah disangkakan oleh penyidik, yang kemudian hal itu berujung vonis pidana penjara oleh Pengadilan (Hakim) kepada para pecandu dan korban penyalahgunaan narkotika. ${ }^{21}$

Seharusnya aparat penegak hukum dapat lebih jeli lagi melihat amanat Undang-Undang dan regulasi lainnya yang mengatur tentang penanganan penyalahguna narkotika. Sudah jelas dikatakan dalam Pasal 54 yang mengutamakan bahkan wajib hukumnya pecandu dan korban penyalahgunaan narkotika untuk menjalani rehabilitasi medis dan rehabilitasi sosial, hal itu diperkuat lagi oleh Peraturan Pemerintah No. 25

21 Risman, Jumlah Anak di Bawah Umur yang Jadi Pengedar Narkoba Meningkat, http://nasional.harianterbit.com/nasional/2 015/04/27/26608/25/25/Jumlah-Anak-diBawah-Umur-yang-Jadi-Pengedar-NarkobaMeningkat, diunduh pada Selasa, 7 Februari 2016, Pukul. 10.37 WIB. 
Tahun 2011 tentang Pelaksanaan Wajib Lapor Pecandu Narkotika. ${ }^{22}$

Peraturan pemerintah tersebut bertujuan untuk memenuhi hak pecandu Narkotika dalam mendapatkan pengobatan dan/atau perawatan melalui rehabilitasi medis dan rehabilitasi sosial. Apa yang dimaksud dalam Peraturan Pemerintah Nomor 25 Tahun 2011 ini pun semestinya dijalankan pula oleh para aparat penegak hukum mengingat Peraturan Pemerintah termasuk dalam hierarki perundangundangan.

Begitu pula apabila dilihat dari sisi hakim, kebijakan rehabilitasi jarang sekali diberikan berdasarkan putusan hakim dan sebagian putusan yang diterima adalah pidana penjara. Padahal, pemberian sanksi terhadap merupakan suatu tindakan yang harus dipertanggungjawabkan dan dapat bermanfaat bagi anak. Setiap pelaksanaan pidana dan tindakan, diusahakan tidak menimbulkan korban, penderitaan, kerugian mental, fisik dan sosial. Pidana dan tindakan tersebut harus pula memenuhi kepentingan anak tersebut, mencegah akibat-akibat yang tidak diinginkan yang sifatnya merugikan. ${ }^{23}$

Namun perlu diketahui bahwa ancaman pidana pada kententuan Pasal 127 dalam Undang-undang No.35 Tahun 2009 tentang Narkotika (UU Narkotika) hanya berlaku bagi orang yang sudah dewasa saja. Sedangkan apabila ada anak dibawah umur yang melanggar ketentuan pasal tersebut untuk diberikan sanksi, hakim harus pula berpedoman pada ketentuan Undang-Undang No.11 Tahun 2012 tentang Sistem Peradilan Pidana Anak (UU Sistem Peradilan Pidana Anak) untuk pemberian jenis dan masa sanksi terhadap anak tersebut. Hal ini sebagai konsekuensi adanya asas lex specialis derogate lex generalis (asas penafsiran hukum yang menyatakan bahwa hukum yang bersifat khusus mengesampingkan hukum yang bersifat umum). ${ }^{24}$

Asas lex specialis derogate lex generalis terkait pidana ini, menurut pendapat Sahardjo tersebut, sistem pembinaan yang awalnya adalah bersifat kepenjaraan berganti menjadi

23 Maidin Gutom, Perlindungan Hukum terhadap Anak dalam Sistem Peradilan Pidana Anak di Indonesia, Refika Aditama, Bandung, 2014, hlm. 156-162

24 Koesno Adi, Diversi Tindak Pidana Narkotika Anak, Setara Press, Malang, 2015, hlm.23. 
sistem pembinaan. Pemahaman ini juga linier dengan pendapat Bismar Siregar, bahwa peranan Hakim dalam memberikan sanksi tidak hanya menghukum, tetapi mengarahkan si pelanggar hukum tersebut dalam pembinaan kesadaran hukum. $^{25}$ Penafsiran pendapat tersebut, sebagaimana tujuan dari pemidanaan penjara yang diatur oleh UndangUndang No. 11 Tahun 2012 tentang Sistem Peradilan Pidana Anak, maka anak yang dijatuhi pidana penjara tersebut yakni wajib ditempatkan di lembaga pembinaan khusus anak (LPKA), karena lembaga khusus ini adalah bersifat lex specialis agar anak dalam menjalani masa pemidanaan bersesuaian dengan kepentingan terbaik anak dalam proses tumbuhkembangnya.

Dalam Undang-Undang No. 3 Tahun 1997 tentang Pengadilan Anak, tidak secara eksplisit mengatur tujuan pemidanaan, namun secara umum dapat dilihat dalam konsiderannya. Tujuan yang hendak dicapai adalah upaya melindungi dalam rangka menjamin pertumbuhan dan perkembangan fisik,

25 Bismar Siregar, Bunga Rampai Karangan Tersebar Bismar Siregar 1, Rajawali, Jakarta, 1989, hlm. 1. mental, dan sosial secara utuh, serasi, selaras dan seimbang. Selain itu dalam penjelasan diuraikan pula bahwa dengan dikeluarkannya Undang-undang tentang Pengadilan Anak, dimaksudkan untuk lebih melindungi dan mengayomi anak agar dapat menyongsong masa depannya yang masih panjang. Dimaksudkan juga untuk memberi kesempatan kepada anak agar melalui pembinaan akan diperoleh jati dirinya untuk menjadi manusia yang mandiri, bertanggung jawab, dan berguna bagi diri, keluarga, masyarakat, Bangsa dan Negara. ${ }^{26}$

Secara teoritis kecenderungan hakim yang selalu menjatuhkan pidana penjara kepada anak dapat dipersoalkan adalah pidana, termasuk di dalamnya pidana penjara, pada dasarnya hanyalah sebuah alat, yaitu alat untuk mencapai tujuan pemidanaan. Apabila penggunaan alat itu tidak dapat memenuhi tujuan yang telah ditentukan, maka tidak ada alasan untuk tetap menggunakan alat itu. Dalam berbagai teori terdapat pemahaman, bahwa pidana penjara sebagai alat untuk mencapai tujuan pemidanaan masih

26 Nandang Sambas, Pembaharuan Sistem Peradilan Anak di Indonesia, Graha IImu, Yogyakarta, 2010, hlm. 27 
diperdebatkan efektifitasnya. Artinya, tidak ada jaminan apabila pelaku tindak pidana pada akhirnya dijatuhi pidana penjara maka dengan sendirinya ia akan kembali menjadi anggota masyarakat yang baik dan taat hukum. Justru yang sering sekali diketahui adalah, bahwa pidana penjara membawa dampak negatif yang sangat merugikan bagi terpidana, khususnya terpidana anak. ${ }^{27}$

Dalam teori treatment (teori pembinaan/perawatan). Treatment sebagai tujuan pemidanaan dikemukakan oleh aliran positif yang berpendapat bahwa pemidanaan sangat pantas diarahkan kepada pelaku kejahatan, bukan pada perbuatannya. Namun pemidanaan dimaksudkan oleh aliran ini untuk memberi tindakan perawatan (treatment) dan perbaikan (rehabilitation) kepada pelaku kejahatan sebagai pengganti dari penghukuman. Aliran ini beralaskan paham determinisme yang menyatakan bahwa seseorang melakukan kejahatan bukan berdasarkan kehendaknya karena manusia tidak mempunyai kehendak bebas dan dibatasi oleh berbagai faktor, baik watak pribadinya, faktor biologis, maupun faktor lingkungan ${ }^{28}$

Selain itu, putusan hakim dapat dilakukan dengan didasarkan pada Peraturan Kepala Badan Narkotika Nasional (Perka BNN) No. 11 Tahun 2014 Tentang Tata Cara Penanganan Tersangka Dan/Atau Terdakwa Pecandu Narkotika Dan Korban Penyalahgunaan Narkotika Ke Dalam Lembaga Rehabilitasi yaitu dengan meminta melakukan asesmen dengan rekomendasi Tim Asesmen Terpadu yang telah dibentuk di setiap provinsi daan kabupaten/kota.

Begitu juga dalam Pasal 60 ayat (3) Undang-Undang No. 11 Tahun 2012 tentang Sistem Peradilan Pidana Anak disebutkan bahwa Hakim wajib mempertimbangkan laporan penelitian kemasyarakatan dari Pembimbing Kemasyarakatan sebelum menjatuhkan putusan perkara. Salah satu unsur penting dalam peradilan pidana anak adalah Probation Officer yang di Indonesia dilakukan oleh BISPA (Bimbingan Pemasyarakatan dan Pengentasan Anak) yang bertugas menyelidiki latar belakang sosial dan

28 Marlina, Hukum Penitensiere, PT Refika Aditama, Bandung, 2011, hlm. 59-60

27 Kusno Adi, op.cit, hal. 89 
budaya seorang anak sampai melakukan tindak pidana. ${ }^{29}$

Pada kenyataannya pertimbangan yang terdapat pada pasal-pasal dan peraturan perundang-undangan dan hasil penelitian kemasyarakatan yang dilakukan oleh Bapas sering tidak digunakan oleh hakim dalam memutuskan perkara anak pelaku tindak pidana penyalahgunaan narkoba. Hal ini dapat diketahui dari data Bapas yang salah satunya diperoleh dari Bapas Kelas I Jakarta Selatan yang menunjukkan bahwa hanya sedikit saran Bapas untuk Rehabilitasi dipertimbangkan pada kasus anak penyalahgunaan narkoba.

Walaupun tim asesmen terpadu telah terbentuk, namun belum terimplementasikan dengan baik. Hal ini dikarenakan belum adanya koordinasi dari berbagai pihak terkait dalam menangani kasus yang berkaitan dengan anak pelaku tindak pidana penyalahgunaan narkoba. Padahal Tim Asesmen Terpadu dapat dilakukan sejak proses penyidikan. Adapun proses yang perlu dilakukan sebagaimana tertuang dalam Peraturan Kepala Badan

29 Sunaryo, Perlindungan Hukum atas Hak Asasi Manusia bagi Anak dalam Proses Peradilan Pidana, Jurnal Dinamika Hukum, Vo. II, No. 2. Edisi Mei 2002, hlm. 89.
Narkotika Nasional Nomor 11 Tahun 2014 adalah penyidik mengajukan permohonan tertulis kepada Tim Asesmen Terpadu (TAT) untuk dilakukan asesmen paling lama 2 x 24 (dua kali dua puluh empat jam), sedangkan TAT melakukan asesmen maksimal 2 x 24 jam (dua kali dua puluh empat jam) sejak diterimanya berkas permohonan dari penyidik.

Mengenai jumlah TAT minimal dua tim atau lebih dengan anggota tim yang berbeda, tergantung dari banyaknya beban kerja. Keanggotaan TAT terdiri dari Tim Dokter dan Tim Hukum. Untuk Tim Hukum beranggotakan masing-masing satu orang terdiri dari unsur Polri yang ditunjuk oleh Dir IV Narkoba di tingkat pusat, Dir Narkoba Polda/ Kasat Narkoba Polres di tingkat Provinsi/ Kabupaten/ Kota, unsur BNN yang ditunjuk oleh Deputi Pemberantasan/ Kepala BNNP/K/Kab, Jaksa yang ditunjuk dari Kejaksaan RI di tingkat pusat, Kejaksaaan Tinggi/ Negeri di tingkat Provinsi/ Kabupaten/Kota dan Kemenkumham (BAPAS) apabila tersangkanya anak.

Dalam Perka BNN No. 11 Tahun 2014 ada beberapa tugas dan wewenang tim hukum, antara lain, pertama, 
riwayat keterlibatan pada tindak kriminalitas; kedua, telaahan atas berita acara pemeriksaan tersangka yang terkait dengan perkara lainnya; dan ketiga, telaahan atas pasal-pasal Undang-Undang No. 35 Tahun 1999 tentang Narkotika, Surat Edaran Mahkamah Agung No. 4 Tahun 2010 tentang Penempatan Penyalahguna Narkotika ke dalam Lembaga Rehabilitasi Medis dan Rehabilitasi Sosial, dan Surat Edaran Jaksa Agung No. SE-002/A/JA/02/2013 tentang Penempatan Korban Penyalahguna Narkotika ke Lembaga Rehabilitasi Medis dan Rehabilitasi Sosial.

Tugas dan wewenang tim hukum yang ketiga, pada penanganan anak sebagai tersangka dan/atau terdakwa pecandu narkotika dan korban penyalahgunaan narkotika berbeda dengan penanganan orang dewasa, karena penanganan anak bersifat lebih khusus (lex specialis) yang mana ada perangkat hukum yang mengatur khusus tentang anak, dan juga hasil telaahan lebih komprehensif.

Oleh karena itu, tim hukum tidak saja mentelaah ketiga produk hukum sebagaimana amanat Peraturan Kepala Badan Narkotika Nasional No. 11 Tahun 2014, yaitu Undang-Undang No.
35 Tahun 1999, Surat Edaran Mahkamah Agung No. 4 Tahun 2010, dan Surat Edaran Jaksa Agung No. SE002/A/JA/02/2013, tetapi juga mentelaah perundang-undangan lainnya yang terkait dengan anak, baik instrumen hukum nasional maupun instrumen hukum internasional, seperti Undang-Undang Perlindungan Anak, Undang-Undang Sistem Peradilan Pidana Anak, dan Konvensi Hak Anak.

Dengan adanya TAT tersebut seharusnya memang prosedur penanganan anak pelaku tindak pidana narkoba dapat terurai secara jelas. Akan tetapi implementasi dilapangan, adanya TAT sering tidak dipergunakan. Hal ini dapat terlihat pada beberapa kasus yang ditemui di lokus penelitian. Dalam kasus tersebut, pihak yang menangani kasus dalam proses peradilan sering melakukan diversi pada anak pelaku tindak pidana penyalahgunaan narkoba yang menurut mereka telah sesuai dengan Undang-Undang Sistem Peradilan Pidana Anak. Bila dicermati, Undang-Undang Sistem Peradilan Anak belum diterapkan sebagaimana mestinya. Hal ini dikarenakan sebagian besar pemberian diversi tanpa persidangan pada anak pelaku penyalahgunaan narkoba diberikan 
tanpa melihat batasan usia. Padahal diversi tanpa persidangan dapat diberikan pada anak dibawah usia 12 tahun didasarkan pada pertimbangan sosiologis, psikologis, dan pedagogis bahwa anak yang belum mencapai umur 12 (dua belas) tahun dianggap belum dapat mempertanggungjawabkan perbuatannya, sebagaimana tercantum dalam penjelasan Pasal 21 ayat (1) Undang-Undang Sistem Peradilan Pidana Anak.

Kurang terimplementasinya TAT juga dapat terlihat pada kurang dilibatkannya Balai Pemasyarakatan Kementerian Hukum dan HAM dalam penanganan kasus anak pelaku tindak pidana penyalahgunaan narkoba padahal Bapas merupakan pihak yang mengetahui perkembangan dari si anak karena mereka telah melaksanakan penelitian kemasyarakatan dan pembimbingan pada si anak sejak dalam proses penyidikan kepolisian. Keterlibatan Kementerian Hukum dan HAM dalam TAT terletak pada Divisi Pemasyarakatan.

Dalam membahas mengenai anak sebagai penyalahguna narkotika dalam Undang-Undang No. 35 Tahun 1999 tentang Narkotika, pada ketentuan pidana terhadap pasal yang mengatur pemidanaan pada setiap orang yang menyalahgunakan narkotika, apabila dimaknai hubungan 'frasa setiap orang' dengan 'frasa anak yang belum cukup umur', maka pidana yang dilakukan anak belum cukup umur adalah disebabkan atau dipengaruhi oleh orang-orang yang sudah cukup umur (frasa setiap orang) untuk menyuruh, memberi atau menjanjikan sesuatu, memberikan kesempatan, menganjurkan, memberikan kemudahan, memaksa dengan ancaman, memaksa dengan kekerasan, melakukan tipu muslihat, atau membujuk anak yang belum cukup umur, baik untuk melakukan tindak pidana maupun menggunakan narkotika. ${ }^{30}$

Dengan demikian ditafsirkan, tidak ada pasal yang mencantumkan anak belum cukup umur sebagai pengguna/pecandu dan penyalahguna yang melakukan tindak pidana, melainkan anak diposisikan sebagai korban. Terkait anak sebagai korban ini, ketentuan pidana hanya berlaku kepada, pertama, pihak yang pada intinya ikut andil atau turut serta supaya anak yang

30 Undang-Undang No. 35 Tahun 2009 tentang Narkotika pada Pasal 133 ayat (1), sebagaimana dimaksud dalam Pasal 111 sampai dengan Pasal 129, dan Pasal 133 ayat (2). 
belum cukup umur melakukan tindak pidana termasuk anak yang mengedarkan narkotika. Kedua, pidana berlaku kepada pihak yang pada intinya ikut andil atau turut serta supaya anak yang belum cukup umur menggunakan narkotika.

Ketiga, pidana berlaku pada orang tua/wali pecandu narkotika belum cukup umur yang tidak melaporkan kepada pusat kesehatan masyarakat, rumah sakit, dan/atau lembaga rehabilitasi medis dan rehabilitasi sosial yang ditunjuk oleh Pemerintah untuk mendapatkan pengobatan dan/atau perawatan melalui rehabilitasi medis dan rehabilitasi sosial. Keempat, pengenaan pidana bagi pecandu narkotika yang sudah cukup umur dan keluarga dari pecandu tersebut, jika tidak melaporkan diri. ${ }^{31}$

Selain itu, SEMA yang hierakinya di bawah undang-undang tidak mengatur tempat khusus bagi anak belum cukup umur yang melakukan tindak pidana narkotika dengan hasil tes negatif narkotika, karena dalam Undang-Undang No. 35 Tahun 2009 tidak diatur tempat khusus bagi anak belum cukup umur yang

${ }^{31}$ Ibid, Pasal 128 ayat (1) dan Pasal 134 ayat (1). menyalahgunakan narkotika dengan hasil tes negatif.

Hal yang sama juga pada Surat Edaran Jaksa Agung No. SE002/A/JA/02/2013 tentang Penempatan Korban Penyalahguna Narkotika ke Lembaga Rehabilitasi Medis dan Rehabilitasi, yang didasarkan pada Undang-Undang No. 35 Tahun 1999 tentang Narkotika dalam Pasal 54 dan Pasal 55 serta telah dijabarkan pada Peraturan Pemerintah No. 25 Tahun 2011 dalam Pasal 13 dan Pasal 14. Artinya Surat Edaran Jaksa Agung tersebut, juga tidak mengatur tidak pidana narkotika yang dilakukan anak belum cukup umur dan tempat khusus pembinaan dan pengawasan anak pidana narkotika dengan tidak sebagai pecandu/pengguna narkotika.

Dengan demikian, hasil rekomendasi tim hukum seyogyanya anak belum cukup umur walaupun sebagai pelaku pidana narkotika, tetapi penanganannya berbeda dengan orang dewasa (yang sudah cukup umur), sehingga tempat pendidikan dan pembinaannya disediakan tempat khusus agar anak tidak kembali menjadi penyalahguan narkotika.

Oleh karena itu, perlu penguatan sinergisitas para aparatur penegak 
hukum, terutama dalam rangka pembuatan TAT termasuk keikutsertaan Bapas dalam TAT. Hal ini sejalan pendapat Mardjono yang mengemukakan empat komponen sistem peradilan pidana yaitu kepolisian, kejaksaan, pengadilan, dan lembaga pemasyarakatan diharapkan dapat bekerja sama dan dapat membentuk suatu sistem peradilan pidana yang terpadu. ${ }^{32}$

\section{PENUTUP}

\section{Kesimpulan}

a. Secara umum penanganan anak pelaku tindak pidana penyalahgunaan narkoba hampir sama dengan penanganan kasus anak lainnya, walaupun ada sejumlah perbedaan yaitu, pertama, dalam Undang-Undang Narkotika anak belum cukup umur ditafsirkan sebagai korban bukan sebagai pengguna/pecandu dan penyalahguna yang melakukan tindak pidana, sedang pengaturan pidana ada dalam UU Sistem Peradilan Pidana Anak; kedua, belum adanya persamaan persepsi antar para penegak

\footnotetext{
${ }^{32}$ Mahrus Ali, Membumikan Hukum Progresif,
} Aswaja Presindo, Yogyakarta, 2013, hlm. 32 hukum, terkait rehabilitasi medis atau sosial atau pidana penjara bagi anak; ketiga, rekomendasi tim asesmen terpadu (TAT) sering tidak dimintakan oleh penyidik.

b. Kebijakan rehabilitasi pada anak pelaku tindak pidana penyalahgunaan narkoba seringkali diberikan sebelum sampai tahap persidangan selama bukan merupakan perbuatan pengulangan. Akan tetapi kebijakan rehabilitasi jarang sekali diberikan berdasarkan putusan hakim dan sebagaian putusan yang diterima adalah pidana penjara. Hal ini menjadi salah satu hal yang perlu diperhatikan, mengingat telah terbentuknya TAT dalam rangka memberikan perlindungan terhadap hak-hak anak dalam memperoleh kepentingan terbaiknya.

\section{Saran}

a. Mengingat terdapat dua pola penanganan narkoba oleh BNN, maka khusus Penanganan Anak sebagai pelaku tindak pidana penyalahgunaan narkoba, maka Rehabilitasi menjadi pendekatan 
Humanis dalam memberikan perlindungan khusus bagi anak yang berkonflik dengan hukum. Namun pendekatan humanis ini seyogyanya tidak mengesampingkan penegakan hukum dengan tetap menempatkan anak pada Lembaga Pembinaan Khusus Anak (LPKA).

b. Mengingat Tim Asesmen Terpadu (TAT) ini sangat dibutuhkan dalam penanganan anak pelaku tindak pidana penyalahgunaan narkoba, antara lain melakukan penilaian terhadap pelaku tindak pidana narkoba, maka diperlukan pendekatan/basis hak anak terutama dalam memutuskan hasil asesmennya, guna mengupayakan perlindungan hak-hak sipil anak. Terutama mempertimbangakan kepentingan terbaik bagi anak.

c. Dalam hal pembentukan TAT, hendaknya langsung menunjukan balai pemasyarakatan (Bapas) sebagai anggota TAT sebagaimana tugas dan fungsi Bapas dalam penanganan anak yang berkonflik dengan hukum adalah melakukan pendampingan dan pembimbingan anak.

\section{DAFTAR PUSTAKA}

\section{A. Buku}

Badan Narkotika Nasional, Laporan Akhir Survey Nasional Perkembangan Penyalahguna Narkoba Tahun Anggaran 2014, tanpa penerbit, Jakarta, 2014
Bismar Siregar, Bunga Rampai Karangan Tersebar Bismar Siregar 1, Rajawali, Jakarta, 1989.

Gatot Supramono, Hukum Acara Pengadilan Anak, Djambatan, Jakarta, 2000.

John W. Creswell, Qualitative Inquiry and Research Design: Choosing Among Five Tradition, SAGE Publications, London, 1998.

Koesno Adi, Diversi Tindak Pidana Narkotika Anak, Setara Press, Malang, 2015.

Mahrus Ali, Membumikan Hukum Progresif, Aswaja Presindo, Yogyakarta, 2013.

Maidin Gutom, Perlindungan Hukum terhadap Anak dalam Sistem Peradilan Pidana Anak di Indonesia, Refika Aditama, Bandung, 2014.

Marlina, Hukum Penitensiere, PT Refika Aditama, Bandung, 2011.

Nandang Sambas, Pembaharuan Sistem Peradilan Anak di Indonesia, Graha Ilmu, Yogyakarta, 2010. 


Soerjono Sukanto,
Penelitian Hukum, Universitas
Indonesia Press, Cetakan 3,
Jakarta, 1986.

\section{B. Peraturan Perundang-undangan}

Undang-Undang No. 35 Tahun 2014 tentang Perubahan Atas UndangUndang No. 23 Tahun 2002 tentang Perlindungan Anak

Undang-Undang No. 11 Tahun 2012 tentang Sistem Peradilan Pidana Anak

Undang-Undang No. 35 Tahun 2009 tentang Narkotika

Undang-Undang No. 3 Tahun 1997 tentang Pengadilan Anak

Undang-Undang No. 5 Tahun 1997 tentang Psikotropika

Peraturan Pemerintah Republik Indonesia No. 25 Tahun 2011 tentang Pelaksanaan Wajib Lapor Pecandu Narkotika

Peraturan Kepala Badan Narkotika Nasional No. 11 Tahun 2014 Tentang Tata Cara Penanganan Tersangka Dan/Atau Terdakwa Pecandu Narkotika Dan Korban Penyalahgunaan Narkotika Ke Dalam Lembaga Rehabilitasi

Surat Edaran Mahkamah Agung No. 4 Tahun 2010 tentang Penempatan Penyalahguna Narkotika ke dalam Lembaga Rehabilitasi Medis dan Rehabilitasi Sosial.
Penempatan Korban Penyalahguna Narkotika ke Lembaga Rehabilitasi Medis dan Rehabilitasi Sosial.

\section{Jurnal dan Internet}

Aji Mulyana, Perlindungan Hukum Terhadap Perempuan dan Anak Akibat Tindak Pidana Abortus Provokatus Criminalis, Jurnal Wawasan Yuridika, Volume. 1, Nomor. 2, Sepetmber 2017.

M. Rendi Aridhayandi, Focus Group Discution Mengenai Pemahaman Perubahan Aturan Hukum Indikasi Geografis Bagi Masyarakat Pelestari Padi Pandanwangi Cianjur (MP3C) Sebagai Pemegang Hak Indikasi Geografis Terdaftar, Journal Of Empowerment, Volume. 1, Nomor. 2, Desember 2017, hlm. 90.

Sunaryo, Perlindungan Hukum atas Hak Asasi Manusia bagi Anak dalam Proses Peradilan Pidana, Jurnal Dinamika Hukum, Vo. II, No. 2. Edisi Mei 2002

Risman, Jumlah Anak di Bawah Umur yang Jadi Pengedar Narkoba Meningkat, http://nasional.harianterbit.com/na sional/2015/04/27/26608/25/25/Ju mlah-Anak-di-Bawah-Umuryang-Jadi-Pengedar-NarkobaMeningkat

Surat Edaran Jaksa Agung No. SE002/A/JA/02/2013 tentang 